\title{
Effect of protein/essential amino acids and resistance training on skeletal muscle hypertrophy: A case for whey protein
}

\author{
Juha J Hulmi*1 ${ }^{*}$, Christopher M Lockwood² and Jeffrey R Stout²
}

\begin{abstract}
Regardless of age or gender, resistance training or provision of adequate amounts of dietary protein (PRO) or essential amino acids (EAA) can increase muscle protein synthesis (MPS) in healthy adults. Combined PRO or EAA ingestion proximal to resistance training, however, can augment the post-exercise MPS response and has been shown to elicit a greater anabolic effect than exercise plus carbohydrate. Unfortunately, chronic/adaptive response data comparing the effects of different protein sources is limited. A growing body of evidence does, however, suggest that dairy PRO, and whey in particular may: 1) stimulate the greatest rise in MPS, 2) result in greater muscle cross-sectional area when combined with chronic resistance training, and 3) at least in younger individuals, enhance exercise recovery. Therefore, this review will focus on whey protein supplementation and its effects on skeletal muscle mass when combined with heavy resistance training.
\end{abstract}

\section{Review}

Net protein balance (NPB) is defined as muscle protein synthesis (MPS) minus muscle protein breakdown (MPB), or NPB = MPS - MPB. Thus, a significant rise in skeletal MPS (anabolism) and/or reduction in MPB (catabolism), such that NPB remains positive can result in increased skeletal muscle mass accretion. Conversely, a negative NPB, arising from a reduction in MPS and/or increase in MPB, will result in a loss of skeletal muscle. It has clearly been demonstrated that an acute bout of heavy resistance exercise - intermittent exercise of repeated short, high-intensity (60-90\% 1 RM) bouts [1] stimulates a significant increase in MPS. However, NPB remains negative due to a concomitant rise in MPB when resistance exercise and recovery occur under fasted conditions [2-4]. Pre- or post-exercisise ingestion of protein (PRO) or essential amino acid (EAA) can increase MPS and result in a positive NPB [3,5-11]. Furthermore, the majority of studies in humans suggest that PRO/EAA ingestion in the context of a resistance training session

* Correspondence: juha.hulmi@jyu.fi

1 Department of Biology of Physical Activity, University of Jyväskylä, P.O. Box 35, 40014 Jyväskylä, Finland

Full list of author information is available at the end of the article can enhance skeletal muscle hypertrophy in response to chronic resistance training [12-20]. More specifically, $\mathrm{PRO} / \mathrm{EAA}$ intake around the time of resistance exercise, as opposed to nutrient ingestion at times distal to exercise, may be more beneficial for promoting muscle hypertrophy [21,22].

Milk contains two categories/fractions of PRO - whey and casein. About $20 \%$ of the total PRO in commercial bovine milk comes from whey [23-25]. Direct and indirect evidence suggests that whey may be an especially suitable PRO to be used in conjunction with resistance exercise to stimulate muscle hypertrophy $[9,20,26,27]$. If correct, this may contribute to the observed widespread use and sales of whey PRO amongst sports nutrition consumers. This review will, therefore, focus on whey PRO supplementation and resistance training as it pertains to muscle mass adaptations in healthy adults. Some general effects of PRO/EAA will, however, be reviewed first.

\section{Effects of PRO/EAA supplementation on MPS and skeletal muscle hypertrophy}

Heavy resistance training has a well documented positive effect on skeletal muscle size [20,28-31], whereas ingestion of sufficient amounts of PRO/EAA also plays an 
important role in muscle adaptations. For example, in young men, PRO/EAA supplementation in combination with resistance training has been shown to significantly increase myofiber cross-sectional area greater than a non-energetic or carbohydrate placebo [12-15]. Additionally, PRO/EAA has been shown to be more effective than carbohydrate or non-energetic placebo at increasing lean or fat-free body mass and whole muscle cross-sectional area [14-20,32]. Contrary to the aforementioned, some studies have reported that $\mathrm{PRO} / \mathrm{EAA}$ ingestion provides no significant effect on myofiber size or lean body mass during resistance training [33-36]. Overwhelmingly, however, in young males, PRO/EAA has been shown to positively augment the physiological adaptation to exercise. For instance, Andersen et al. [12] investigated the effects of a mostly whey-containing PRO blend versus an isoenergetic carbohydrate, consumed before and after resistance exercise for 14 weeks, in previously untrained young men. Only the PRO group showed type I and II myofiber hypertrophy (18\% and $26 \%$, respectively). Similarly, Hartman et al. [15] reported that consumption of fat-free milk after resistance exercise, for 12 weeks, increased lean mass and type II myofiber crossectional area more than consuming soy or carbohydrate in previously untrained young males. Candow et al. [17], on the other hand, found that both whey and soy PRO increased lean tissue mass more than an isocaloric carbohydrate placebo in healthy, young men. Hulmi et al. [20,37] has also reported that combined PRO ingestion and resistance training in previously untrained males, following an ad libitum diet, provides an augmented physiological adaptation to training. Specifically, ingestion of $15 \mathrm{~g}$ of whey PRO isolate (WPI) immediately before and after resistance exercise, for 21 weeks, increased skeletal muscle cross-sectional area [20] and seemed to accelerate increases in muscle thickness more than ingestion of a non-energetic placebo. No significant effects between groups on direct measures of myofiber size were observed [37]. However, this non-effect may be due to large variation inherent within the measurement. Interestingly, the significant differences observed between groups occurred despite both groups consuming a relatively large habitual ingestion of PRO from diet alone ( 1.4-1.5 g/kg bodyweight/day).

Conversely, in older males, the effects of PRO/EAA supplementation on exercise adaptation have been less clear. Verdijk et al. [36] reported no effect of casein versus a non-energetic placebo when consumed before and after resistance exercise in older men, and Godard et al. [34] showed no effect of 12 weeks of combined resistance training and low-dose EAA ingestion in older males. Similarly, Kukuljan et al. [38] reported no significant between-group differences in older males involved in 18 months of resistance training or with those also consum- ing fortified milk twice daily. Main effects for time were, however, noted for subjects in the milk plus exercise group for increases in lean mass and muscle cross-sectional area. Therefore, the long-term data thus far would appear to support the occurrence of a more robust MPS $[39,40]$, or possibly altered $\mathrm{MPB}$ response from $\mathrm{PRO} /$ EAA ingestion in younger populations than older. However, this difference may not always exist, at least with large doses of PRO ingestion [41]. Katsanos et al. [39] showed that older individuals may require a higher absolute dose of leucine to effectively stimulate MPS. Additionally, PRO source and/or form may significantly affect the MPS response observed in older subjects [10]. It is evident that more long term studies comparing healthy younger and older subjects are needed, as are more studies in healthy female populations. However, the few available studies involving females seems to suggest that PRO ingestion is comparably effective within this population as in healthy young males [32].

It must also be noted that a large variability exists to resistance training only, at least in previously untrained subjects [42]. Therefore, any effect of PRO/EAA supplementation within previously untrained subjects may be overshadowed by a large standard error of means. This may be especially true when the intervention is of short duration and/or sample sizes are small. Similarly, though some body composition methods commonly used to report changes in fat-free mass - dual-energy $x$-ray absorptiometry or air displacement plethysmography can accurately track changes, their respective total statistical error of measure may be too large to assess small, but significant changes between groups/interventions [43]. Such considerations should be accounted for in future trials to increase statistical power and reduce the probability of type II error confounding study conclusions.

\section{PRO/EAA ingestion may enhance recovery from heavy resistance exercise}

Several studies support the use of EAA or PRO, when supplemented within the context of exercise, to enhance recovery of muscle function as measured $\sim 1-4$ days after heavy exercise [44-49] and to decrease proxy markers of muscle damage or soreness [44-48]. Though increased EAA availability may simply provide a more robust anabolic environment, enhanced recovery may also be explained, in part, by EAA's possible anti-catabolic effect of decreasing whole body myofibrillar protein degradation in the days following strenuous exercise [50]. However, more direct evidence is needed to support the hypothesis that inhibiting catabolism improves recovery and adaptations from heavy exercise. Interestingly, EAA concentration alone likely cannot entirely explain the improved rate of recovery for measures of peak isometric 
torque observed by Buckley et al. [46]. Specifically, when previously untrained subjects consumed either $25 \mathrm{~g}$ WPI or $25 \mathrm{~g}$ of its extensive hydrolysate (WPH), peak isometric torque was fully recovered by 6 hours post-fatiguing eccentric exercise for subjects consuming the WPH, whereas recovery was still significantly depressed by 24 hours post-exercise in both the WPI and placebo groups [46]. However, no differences between groups were observed for muscle soreness or proxy measures of muscle damage (e.g., creatine kinase) for up to 24 hours postexercise. Thus, more research needs to be conducted to assess changes over a greater time period.

In the case of whey PRO or its hydrolysates, whether consumed in the absence or presence of carbohydrate, one explanation may be that whey provides a post-exercise insulin response [51,52] (or augments the response from carbohydrate) such that NPB can be slightly smaller and glycogen resynthesis occurs more rapidly; thus, the recovery from exercise may be enhanced. Power et al. [52] showed that $45 \mathrm{~g}$ of WPI or its extensively hydrolyzed WPH yielded similar rates of gastric emptying when consumed by healthy adults under fasted conditions. However, 3-hour area under the curve and peak insulin response for the WPH was found to be $43 \%$ and $28 \%$ greater than for WPI, respectively. Similarly, Morifuji et al. [53] reported that rat skeletal muscle glycogen concentrations were significantly greater two hours after completing a glycogen-depleting exercise bout when carbohydrate+WPH was consumed immediately post-exercise $(\mathrm{CHO}+\mathrm{WPH}>\mathrm{CHO}+\mathrm{WPI} \approx \mathrm{CHO}+\mathrm{BCAA}>$ $\mathrm{CHO}+\mathrm{CPH} \approx \mathrm{CHO} ; \mathrm{CHO}, \mathrm{BCAA}$ and $\mathrm{CPH}$ refer to carbohydrate, branched-chain amino acids, and casein PRO hydrolysate, respectively). Interestingly, Morifuji et al. [54] identified several BCAA-containing dipeptides from hydrolysis of the whey fraction, beta-lactoglobulin, that were shown to significantly increase glucose uptake in L6 myocytes and glycogen concentrations in isolated skeletal muscles. Whether these results can be duplicated in humans and can be achieved in response to heavy resistance training remains to be seen.

\section{Mechanisms underlying the effects of PRO/EAA ingestion on MPS and recovery}

High-quality PRO such as whey effectively stimulates the synthesis of myofibrillar and sarcoplasmic protein fractions in muscle under resting conditions and in response to resistance exercise [9]. Possibly the most important component of high-quality PRO may be its large concentration of BCAAs. Specifically, BCAAs [55,56] appear to elicit similar mTOR signaling as occurs in response to intact whey [37] and casein hydrolysate [57] when provided in the context of a bout of resistance exercise. However, based upon animal and cell culture studies, only leucine is required to induce protein synthesis [58-60] and mTOR signaling [61]. In vivo human studies are needed to validate this hypothesis. The precise mechanism by which amino acids activate mTOR may involve increased intracellular $\mathrm{Ca}^{2+}$, which in turn activates a class III PI3 kinase human vacuolar protein sorting 34 (hVps34) [62]. In the activation of mTOR by amino acids, Rag GTPases [63,64], Rheb [65] and MAP kinase 4 [66] may also be utilized.

In theory, enhanced exercise recovery due to PRO/EAA ingestion may also be partially explained by the results of a recent study in older adults. Just one week of a low protein $\operatorname{diet}(0.5 \mathrm{~g} / \mathrm{kg}$ b.w. $/ \mathrm{d})$ decreased several transcript levels in muscle that relate positively to cell proliferation, and increased transcript levels that negatively regulate cell proliferation [67]. Moreover, gene expression of cyclin-dependent kinase 2 (cdk2), a factor that positively affects cell proliferation $[68,69]$ and animal size [69], has been shown to increase in humans after acute and chronic bouts of resistance exercise, but only when whey PRO is ingested around training times [20,70]. Regardless of the cellular mechanisms positively affected by exercise and PRO/EAA ingestion, enhanced recovery enables greater training volume [71]. Increased training volume alone may support increased muscle hypertrophy. As more studies assessing the effects of PRO/EAA at the cellular level are conducted, a viable theory will likely surface to more directly address these issues.

\section{Effect of PRO/EAA timing on MPS and skeletal muscle hypertrophy}

PRO/EAA intake immediately following or immediately before and after resistance exercise, as opposed to nutrient ingestion at times distal to exercise, has been reported in some studies to be more beneficial for promoting muscle hypertrophy in both previously untrained [21] and trained subjects [22]. As has been speculated (see review: [72]), one reason for the timing effect may be increased skeletal muscle circulation, and thus nutrient transport during and for a short period following exercise. Thus, there seems to exist an enhanced time-window for the uptake of amino acids and glucose into muscle [2,73-75]. If true, this appears to occur concomitantly within the time period when MPS has the greatest elevation in response to exercise [76] and may explain why early nutrient timing after exercise seems to be especially beneficial in increasing MPS (see Burd et al. [77]).

It may be possible, however, that timing of nutrient ingestion does not always significantly affect resistance training adaptations. This may be the case at least for some PRO sources or for PRO in the absence of carbohydrates. As evidence, a recent 10-week study by Hoffman et al. [78], in resistance-trained athletes, reported that PRO-alone, consumed either immediately before and after exercise or in the morning and evening, did not sig- 
nificantly affect strength, power, or changes in body composition. The PRO source was a blend of collagen hydrolysate, WPI and casein. Unfortunately, total daily PRO intake for the morning-evening group increased significantly more than for the pre-/post-exercise group. Therefore, it is possible that the effects observed may not be predictive for all PRO, and in fact a positive bias for the morning-evening group may have confounded the results altogether. However, it may be possible that the subjects' high degree of prior strength training experience may have also created a "ceiling effect" requisite of a greater sample size and smaller effect size to observe small, but statistically significant between-group changes. In a study in previously untrained subjects involved in eight weeks of resistance training, $70 \mathrm{~g} / \mathrm{d}$ of PRO $(82 \%$ as the slow digesting PRO, casein [79]) reportedly increased fat-free mass when consumed in the morning and evening (five hours after resistance exercise) as opposed to being consumed in the morning and afternoon (immediately before training) [80]. Interestingly, these results may suggest that ingestion of slow digesting PRO, such as casein, prior to a period of prolonged fasting (e.g., bedtime) could be advantageous to increasing muscle hypertrophy. However, it is also possible that the aforementioned Burk et al. study [80] more practically provides evidence to support the preferential need for post-exercise $\mathrm{PRO} / \mathrm{EAA}$ supplementation, so long as previously untrained subjects consume PRO/EAA within five hours after exercise. Specifically, peak MPS response has been shown to be delayed in previously untrained individuals [81].

The majority of available data has concluded that whey or total milk PRO (whey+casein) ingestion immediately after resistance training better augments the MPS response beginning at $\sim 1-3$ hours post-exercise, compared to recovery under fasting conditions or consumption of carbohydrates or soy immediately post-exercise [5-11]. Moreover, in a fasted state, a decrease in MPS during or immediately after resistance exercise may be prevented by provision of EAAs before and/or during exercise [82-84]. A recent study reported no increase in post-exercise MPS following EAA ingestion $1 \mathrm{~h}$ pre-exercise as compared to exercise in the absence of EAA's [80]. In another study, positive but similar leg net amino acid balance (an indirect marker of protein synthesis) was observed post-exercise when $20 \mathrm{~g}$ of whey protein was ingested immediately before exercise or $1 \mathrm{~h}$ postexercise [5]. Contrastingly, an earlier study from the same group reported that the ingestion of EAAs and $\mathrm{CHO}$ immediately before resistance exercise produced a larger increase in leg net amino acid balance compared to $\mathrm{EAA}+\mathrm{CHO}$ provided immediately postexercise [73]. Explanations for the apparently confounding results of the prior study [73] may be that the length of the fasting period prior to the intervention was of too long a duration and/or an artifact, such as pooling of amino acids within muscle may have occurred. Moreover, the observation of a 20 -fold increase in blood flow would seem to indicate that it is unlikely the results completely represented MPS [73]. Therefore, the question remains whether post-exercise PRO/EAA ingestion alone is enough, especially under normal dietary situations (eg, non-fasted), to elicit optimal muscle anabolism in response to exercise. This probably depends at least on the timing of the last meal before exercise and possibly on the duration/intensity/type of exercise. Lastly, non-significant trends observed by Beelen et al. [83] indicate that PRO ingestion prior to exercise may slow the breakdown of whole-body protein during resistance exercise. However, even if whole-body protein breakdown is reduced during exercise, what effect if any this may have on MPB and eventually on muscle adaptation, remains to be explored. Mindful, of course, that a change in MPS contributes more to the NPB of muscle than a change in PRO degradation $(\mathrm{NPB}=\mathrm{MPS}-\mathrm{MPB})$ after a bout of resistance exercise with or without nutrient ingestion [85].

\section{Effect of PRO/EAA dose on MPS and skeletal muscle hypertrophy}

As few as $10 \mathrm{~g}$ of whey PRO has been shown to effectively stimulate MPS following resistance exercise [8]. However, the optimal PRO/EAA dose to elicit both the most dramatic rise in acute MPS and chronic muscle hypertrophy adaptations has yet to be fully elucidated. Acute studies utilizing egg PRO [86] or EAA [40] seem to indicate a plateau in MPS from the ingestion of between 20-40 $\mathrm{g}$ of intact PRO, or approximately 9-10 g of EAA, respectively. In agreement (to the existence of a plateau effect), no difference in mixed MPS was observed in a recent study involving the ingestion of 30 or $90 \mathrm{~g}$ of PRO from intact beef [87]. Whether or not such a plateau effect is predictive and independent of PRO source has yet to be determined. Similarly, subject-specific dosing and resistance training variables (e.g., volume, intensity, etc.) may also have an effect on the optimal PRO dose. Frequency of PRO dosing is also in its infancy and requires more analyses. For example, it would appear from the available acute MPS data that small (delivering $10 \mathrm{~g}$ EAA), frequent (every 2-5 hrs) PRO feedings are ideal for maintaining a positive NPB in skeletal muscle, at least when consuming a fast-acting EAA source [40]. However, some studies suggest that larger, less frequent PRO/EAA containing feedings provide similar or possibly better responses on lean body mass and protein balance $[88,89]$. More studies are clearly needed to fully address this issue and to determine if, for example, the optimal frequency and/or dose is a protein source dependent phenomenon. 


\section{Effect of protein source on MPS and skeletal muscle hypertrophy}

The literature is relatively sparse in comparing the acute or chronic effects of PRO source on MPS or muscle hypertrophy, respectively. Greater peak leucine net balance over time (indirect estimate of net muscle protein synthesis) was observed for whey versus casein PRO when ingested $1 \mathrm{~h}$ post-exercise, though no significant differences in net phenylalanine balance were observed [90]. A recent study by Tang et al. [11] showed that whey PRO appears to promote a larger MPS response than either casein or soy, at least during the first three hours post-ingestion; both at rest and after resistance exercise in young, healthy males. In fact, at rest, whey was shown to be $\sim 93 \%$ and $\sim 18 \%$ more effective than casein and soy, and whey was $\sim 122 \%$ and $\sim 31 \%$ more effective than casein and soy following exercise, respectively. It should be noted that WPH was used in the aforementioned study, whereas the soy and casein were intact. It may be probable, though, due to the large differences observed between the proteins, that WPI or whey PRO concentrate (WPC) would have provided similar results. However, recent results $[46,53]$ would seem to indicate that at least some differences in acute effects may occur in response to WPH versus intact whey. Whether such acute differences between the intact and hydrolysed PRO sources summate over time and reveal significant chronic effects is an area of needed research.

Few long-term studies comparing different PRO sources have been published thus far. Hartman et al. [15], for example, observed greater gains in fat-free mass and muscle hypertrophy in response to 12 weeks of resistance training with ingestion of fat-free milk versus soy. Additionally, Cribb et al. [26] reported a five-fold increase in lean body mass from supplementation with hydrolyzed whey PRO isolate versus intact casein, when combined with 10 weeks of resistance training in recreational bodybuilders. Candow et al. [17] and Brown et al. [91], however, reported no significant differences on changes in body composition in response to combined resistance training and either whey or soy PRO ingestion. Kalman et al. [92] also found no differences between groups for lean body mass when examining the effects of 12 weeks of resistance training combined with $50 \mathrm{~g} / \mathrm{d}$ PRO supplementation from either a whey PRO blend (50:50 ratio of WPI:WPC), soy concentrate, soy isolate, or a 50:50 ratio of soy isolate and the whey blend. Although interesting, some limitations within the aforementioned pilot study [92] do exist, as is evident by the author's own statement that "the data is considered inferential and not conclusive". That is, the sample size was too small to yield high statistical power. Indeed, of many of the studies to date, statistical power has likely not been high enough to adequately differentiate the effects between PRO source. A meta-analysis of studies ( $>200$ subjects) in which PRO supplementation was used to promote muscle hypertrophy in combination with resistance training, was recently published that addresses this issue of statistical power [93]. Specifically, Phillips et al. [93] discovered that whey PRO elicited significantly greater gains in lean body mass than soy or carbohydrate, but was not significantly different than the effects of milk PRO.

One explanation for the superiority of dairy PRO at increasing skeletal muscle mass may be explained by the results observed by Fouillet et al. [94] that reported significantly greater peripheral nitrogen retention from milk PRO than soy PRO; soy was found to have a more profound effect on splanchnic protein synthesis. Additionally, the rate at which amino acid concentrations rise may significantly affect MPS [11,95]. For example, whey is absorbed rapidly and is relatively short-acting, quickly and vastly increasing whole body protein synthesis (estimated by non-oxidative leucine disposal) compared to casein $[79,96]$. Paradoxically, it has been proposed that whey may have a negligible, or at least smaller decreasing effect on whole body protein breakdown (estimated by endogenous leucine rate of appearance) than may occur in response to slower acting PROs such as casein [79], but not all studies agree with this [97].

The effects of PRO sources other than milk or soy, on muscle hypertrophy, are both fewer in number and more equivocal. For example, Campbell et al. [98] showed that a meat-containing, as opposed to a lacto-ovovegetarian diet provided greater gains in fat-free mass and skeletal muscle mass during resistance training in older men. These results were refuted by a later study [99]. Though lean beef and other high quality, PRO-rich foods (e.g., eggs) can induce a robust increase in muscle protein synthesis $[86,87,100]$, clearly more studies comparing different PRO sources are needed to assess chronic adaptations when combined with resistance training.

\section{Whey protein}

Human milk contains two categories/fractions of PRO whey and casein - in an 90:10 ratio during early lactation; whereas the ratio shifts to approximately $60: 40$ and 50:50 during mature and late lactation, respectively [101]. By comparison, only $\sim 20 \%$ of the total PRO in commercial bovine milk comes from whey [23-25]. Camel's milk, a source growing in popularity but lacking in human physiological response data, is only $\sim 15 \%$ whey [102]. Comprising whey are the PRO components $\beta$-lactoglobulin ( 50-55\%), $\alpha$-lactalbumin ( 20-25\%), glycomacropeptide ( 10-15\%), immunoglobulins ( 10-15\%), serum albumin ( 5-10\%), lactoferrin ( 1\%), lactoperoxidase $(<1 \%)$, and other minor proteins such as $\beta$-microglobulin, lysozyme, insulin-like growth factors and $\gamma$-globulins [23$25,103,104]$. Of the aforementioned whey fractions, $\beta$ - 
lactoglobulin may be especially important for stimulating MPS according to at least one recent study in older rats that compared the effects of leucine-rich PROs on postprandial MPS [105]. Notably, $\beta$-lactoglobulin, representing about $50-55 \%$ of the PRO in whey, is a major source of BCAA and is composed largely of the BCAA leucine approximately $14.5 \%$ of $\beta$-lactoglobulin is made up of leucine residues. The potential, critical role of a PRO's leucine concentration on eliciting MPS has thus far only been observed in rats, however [106]. Interestingly enough, recent evidence also seems to indicate that native, or peptide-bound leucine, as opposed to free-form leucine may be utilized most efficiently [107]. This may imply that intact whey or its hydrolysated peptides may provide a superior MPS response than equivocal amounts of free leucine when consumed post-exercise. Similarly, whey is considered a high-quality PRO because of its abundance of EAA [23] which are necessary for stimulating protein synthesis and supporting muscle growth (Table 1) $[108,109]$. Whey is also classified as a "fast" PRO due to the rate at which its consumption leads to an increase in amino acid availability $[10,79,110]$, which may be important for athletes and specifically valuable around workouts. The rate and concentration of amino acid availability may also be predictive of the MPS response [95], which may explain the superiority of whey versus soy or casein at stimulating MPS [11]. In the future, more research should be done comparing protein fractions in whey on MPS [105] and body composition [111], especially when combined with exercise.

\section{Whey protein supplements}

Whey PRO is categorized, commercially, as either whey PRO concentrate (WPC), whey PRO isolate (WPI), or whey PRO hydrolysate (WPH, or hydrolyzed whey). WPC, or native whey, may contain $29 \%$ to $89 \%$ total protein by volume $(\mathrm{g} / 100 \mathrm{~g})$, with the remaining nutrient composition coming from carbohydrate (predominantly lactose) and lipid. However, the relatively small differences in lipid and carbohydrate concentrations between WPC's of high protein concentration (e.g., $\geq 70 \%$ ), and WPI or a typical WPH, may not significantly affect the rate of gastric emptying and amino acid absorption as compared to what has been observed in response to WPI and WPH $[112,113]$. In fact, addition of milk fat may offer a slightly positive effect on post-exercise protein balance according to at least one study that compared the effects of whole versus fat-free milk [114]. However, to date, no data exists that has compared the acute absorption kinetics and MPS response, or long-term physiological adaptation from WPCs of varying concentrations to other WPCs, WPIs or WPHs. Interestingly enough, WPC-70 and WPC-80 (70\% and $80 \%$ concentrations of protein, respectively) are the most common forms of whey PRO used within sports supplements, largely due to current raw material pricing and possibly improved taste characteristics when compared to either WPI or various forms of WPH [115]. Paradoxically, the vast majority of whey PRO research has utilized either WPI or WPH. WPI contains $\geq 90 \%$ total protein by volume and very little, or insignificant amounts of lactose and lipids. The low lactose content of WPI may be of importance for individuals

Table 1: Approximate Essential Amino Acid Profile of Various Protein Sources

\begin{tabular}{|c|c|c|c|c|c|c|}
\hline $\begin{array}{l}\text { ESSENTIAL } \\
\text { AMINO ACID }\end{array}$ & $\begin{array}{c}\text { MILK } \\
\text { PROTEIN } \\
\text { ISOLATE }\end{array}$ & $\begin{array}{c}\text { WHEY } \\
\text { PROTEIN } \\
\text { ISOLATE }\end{array}$ & $\begin{array}{c}\text { WHEY } \\
\text { PROTEIN } \\
\text { HYDROL. }\end{array}$ & CASEIN & $\begin{array}{l}\text { SOY PROTEIN } \\
\text { ISOLATE }\end{array}$ & EGG PROTEIN \\
\hline Isoleucine & 4.4 & 6.1 & 5.5 & 4.7 & 4.9 & 5.7 \\
\hline Leucine & 10.3 & 12.2 & 14.2 & 8.9 & 8.2 & 8.4 \\
\hline Lysine & 8.1 & 10.2 & 10.2 & 7.6 & 6.3 & 6.8 \\
\hline Methionine & 3.3 & 3.3 & 2.4 & 3.0 & 1.3 & 3.4 \\
\hline Phenylalanine & 5.0 & 3.0 & 3.8 & 5.1 & 5.2 & 5.8 \\
\hline Threonine & 4.5 & 6.8 & 5.5 & 4.4 & 3.8 & 4.6 \\
\hline Tryptophan & 1.4 & 1.8 & 2.3 & 1.2 & 1.3 & 1.2 \\
\hline Valine & 5.7 & 5.9 & 5.9 & 5.9 & 5.0 & 6.4 \\
\hline Total BCAAs & 20.4 & 24.2 & 25.6 & 19.5 & 18.1 & 20.4 \\
\hline Total EAAs & 42.7 & 49.2 & 49.8 & 40.7 & 36.0 & 42.3 \\
\hline
\end{tabular}

Approximate concentration of essential and branched chain amino acids (EAA and BCAA, respectively) present within various forms of commercially available protein ( $\mathrm{g} / 100 \mathrm{~g}$ ). Adapted from [27]. Casein is the average of reported values for Calcium Caseinate, Sodium Caseinate, and Potassium Caseinate; Whey Protein Isolate is the average of reported values for lon-Exchange and Cross-Flow Microfiltrated Whey Protein Isolates. Hydrol. is hydrolysate. 
with lactose intolerance, especially when large amounts of whey or other dairy products are consumed daily. Also, WPI may be more suitable than WPC when used in combination with a very-low-carbohydrate (ketogenic) diet.

PRO can also be enzymatically or otherwise hydrolyzed (i.e., partially "pre-digested") during manufacturing, producing smaller peptides which may accelerate the absorption and utilization of amino acids [116]. Accordingly, as discovered by Koopman et al. [95] when comparing intact casein versus casein hydrolysate, the faster rate of amino acid appearance and greater peak amino acid concentration obtained from casein hydrolysate may ( $p$-value was reported as $p=0.10$ ) combine to accentuate the MPS response to exercise [95]. However, the data comparing whey PRO to its hydrolysate is even less clear. In fact, whey may already be an effectively fast-acting source such that hydrolysis does not further augment its gastric emptying [113] or substantially accelerate the increase in blood amino acid concentrations [52]. One limitation to our current understanding of the differences between native whey and its hydrolysate is that all hydrolysis does not yield the same homogenous PRO containing endproduct. Instead, degree of hydrolysis varies considerably and is rarely reported in studies and almost never on product labels; nor is the concentration of PRO fragments by molecular weight generally disclosed within the literature. For example, to possibly optimize PEPT-1 diand tri-peptide transporters for rapid amino acid absorption and to eliminate allergenicity for some of the large dairy proteins, it has previously been recommended that the majority of PRO fractions be $\leq 0.5 \mathrm{kDa}$ in molecular weight [117]. It could be argued, however, that such extensive hydrolysis may ameliorate possible positive effects from some of the larger whey peptides [23]. Despite absorption kinetics of whey versus its hydrolysates being equivocal at the moment, WPH has been shown to yield a significantly greater insulin response compared to either WPI or WPC [52,113]; and, as mentioned earlier, at least one acute training study in humans has reported improved recovery from WPH versus its WPI source material [46]. Thus, it is possible that WPH may elicit an enhanced effect on muscle hypertrophy when combined with chronic resistance training. Indeed, data collection has recently concluded within our laboratory at the University of Oklahoma to address this very question. Also, see Manninen [116] for a recent review on PRO hydrolysates.

\section{Are the effects of whey protein simply due to its constituent essential amino acids?}

As alluded to previously, the effects of whey on muscle adaptations may not be solely dependent upon its EAA concentration. A study that may confuse that argument was one in which the consumption of $15 \mathrm{~g}$ of EAA almost doubled the muscle protein balance in elderly subjects, compared to consuming whey [118]. Of note, however, the subjects consumed isocaloric amounts of either EAA or whey, and thus the whey trial consisted of $\sim 50 \%$ less EAA. From this study, it would appear that whey may be energetically less efficient than consumption of its constituent EAA for increasing muscle protein balance, at least for elderly individuals, as its constituent non-essential amino acids do not seem to be as important in enhancing protein balance/synthesis $[3,108,109]$. Contrastingly, acute whey PRO ingestion (15 g), under resting conditions and in elderly men and women, resulted in greater muscle protein balance than consumption of its constituent EAAs $(6.72 \mathrm{~g})$ or non-essential amino acids $(7.57 \mathrm{~g})$ [10]. This result may suggest that something other than EAAs within whey are important for muscle hypertrophy. For example, it is possible that via the PEPT-1 cotransporters' high capacity, low specificity rate of transport, and an apparent increased transport affinity for L-valine bound peptides, that the bound form of an EAA may be more efficiently utilized than when delivered in its free-form [119]. Similarly, new discoveries continue to surface regarding bioactive peptides present within dairy, and specifically in whey that may facilitate improved recovery and antioxidative capacity to support physiological adaptations to exercise [104]. However, possible long term superiority of whey compared to its constituent amino acids (all, or just its EAAs) is not known.

\section{Whey protein and leucine}

It is probable that the most important component in whey, for increasing protein synthesis and skeletal muscle size, is its high concentration of the BCAA, leucine (see Table 1). Leucine, acting as a signaling molecule in the mTOR cascade $[61,120]$, has been shown to be a critical amino acid for increasing skeletal muscle protein synthesis, both in vitro [58] and in vivo in humans [39] and rats $[59,105]$. Leucine may also be involved in suppressing muscle protein degradation, according to investigations in vitro [58] and in vivo in humans [121]. However, if recent data involving rodents can be duplicated in humans, leucine concentrations from whey may only affect peak activation of skeletal MPS but not the duration of MPS or duration of mTOR signaling [106]. Similarly, despite the positive effects of leucine per se, it likely is not the sole factor responsible for whey-induced adaptations to resistance training. For example, adding leucine to intact protein has been shown to offer little, if any, effect on protein synthesis and protein balance when consumed after resistance exercise [7,122,123], and $7.5 \mathrm{~g} / \mathrm{d}$ of supplemental leucine for three months was not shown to increase muscle mass or strength in elderly males [124]. However, the latter study did not include training, or may 
be indicative of what Moore et al. [9] found regarding compartmental/fraction-specific protein synthesis in response to PRO feeding alone versus in combination with resistance exercise. Also, results by Katsanos et al. [39] imply that a higher leucine threshold is necessary to stimulate protein synthesis in older adults. And lastly, it is possible that free-form versus native/bound leucine may yield varying efficacy. Thus, there still exists a need to adequately assess the long-term effects of supplemental whey versus leucine, in combination with resistance exercise, on MPS and muscle hypertrophy.

\section{Conclusion}

Most, but not all studies have shown that supplementation of whey alone or with carbohydrates immediately after and possibly before and during resistance exercise can enhance the muscle hypertrophy response to resistance training in healthy adults. Such a response seems to at least be the case when comparing the effects of whey versus a non-energetic, or carbohydrate or soy protein alternative. Some studies also suggest that whey may enhance recovery from heavy exercise and possibly decrease muscle damage and soreness. This could, over time, enhance training adaptations by way of increasing training volume or reducing the potential for over-reaching/over-training. However, much is yet to be understood about the effects of whey protein on the physiological response to resistance training. Future research should look to assess the effects of dose response and timing of protein ingestion, compare the effects of various forms/ fractions of whey as well as compare the effects of whey to other protein sources, and assess the effects of whey protein in muscle atrophying diseases, to name a few.

\section{Abbreviations}

BCAA: branched-chain amino acids; CHO: carbohydrates; EAA: essential amino acids; MPB: muscle protein breakdown; MPS: muscle protein synthesis; mTOR: mammalian target of rapamycin; NPB: net protein balance; PRO: protein; WPC: whey protein concentrate; WPH: whey protein hydrolysate; WPI: whey protein isolate

\section{Competing interests}

The authors declare that they have no competing interests.

\section{Authors' contributions}

JJH: Involved in analyses and interpretation of reference material, drafting and revising the manuscript, and giving final approval to the version to be published.

CML: Involved in analyses and interpretation of reference material, drafting and revising the manuscript, and giving final approval to the version to be published.

JRS: Involved in analyses and interpretation of reference material, drafting and revising the manuscript, and giving final approval to the version to be published.

\section{Acknowledgements}

Anssi H. Manninen is thanked for critical evaluation and suggestions for the early versions of the manuscript. The Finnish Cultural Foundation (Juha Hulmi personal grant) supported this research.

\section{Author Details}

'Department of Biology of Physical Activity, University of Jyväskylä, P.O. Box 35, 40014 Jyväskylä, Finland and 2Department of Health \& Exercise Science, University of Oklahoma, Norman, OK 73019, USA

Received: 8 March 2010 Accepted: 17 June 2010

Published: 17 June 2010

\section{References}

1. American College of Sports Medicine: American College of Sports Medicine position stand. Progression models in resistance training for healthy adults. Med Sci Sports Exerc 2009, 41:687-708

2. Biolo G, Maggi SP, Williams BD, Tipton KD, Wolfe RR: Increased rates of muscle protein turnover and amino acid transport after resistance exercise in humans. Am J Physiol 1995, 268:E514-20.

3. Tipton KD, Ferrando AA, Phillips SM, Doyle D Jr, Wolfe RR: Postexercise net protein synthesis in human muscle from orally administered amino acids. Am J Physiol 1999, 276:E628-34.

4. Pitkänen HT, Nykanen T, Knuutinen J, Lahti K, Keinanen O, Alen M, Komi PV, Mero AA: Free amino acid pool and muscle protein balance after resistance exercise. Med Sci Sports Exerc 2003, 35:784-792.

5. Tipton KD, Elliott TA, Cree MG, Aarsland AA, Sanford AP, Wolfe RR: Stimulation of net muscle protein synthesis by whey protein ingestion before and after exercise. Am J Physiol Endocrinol Metab 2007, 292:E71-6.

6. Wilkinson SB, Tarnopolsky MA, Macdonald MJ, Macdonald JR, Armstrong $D$, Phillips SM: Consumption of fluid skim milk promotes greater muscle protein accretion after resistance exercise than does consumption of an isonitrogenous and isoenergetic soy-protein beverage. Am J Clin Nutr 2007, 85:1031-1040.

7. Koopman R, Wagenmakers AJ, Manders RJ, Zorenc AH, Senden JM, Gorselink M, Keizer HA, van Loon LJ: Combined ingestion of protein and free leucine with carbohydrate increases postexercise muscle protein synthesis in vivo in male subjects. Am J Physiol Endocrinol Metab 2005, 288:E645-53.

8. Tang JE, Manolakos JJ, Kujbida GW, Lysecki PJ, Moore DR, Phillips SM: Minimal whey protein with carbohydrate stimulates muscle protein synthesis following resistance exercise in trained young men. Appl Physiol Nutr Metab 2007, 32:1132-1138.

9. Moore DR, Tang JE, Burd NA, Rerecich T, Tarnopolsky MA, Phillips SM Differential stimulation of myofibrillar and sarcoplasmic protein synthesis with protein ingestion at rest and after resistance exercise. $J$ Physiol 2009, 587:897-904.

10. Katsanos CS, Chinkes DL, Paddon-Jones D, Zhang XJ, Aarsland A, Wolfe RR: Whey protein ingestion in elderly persons results in greater muscle protein accrual than ingestion of its constituent essential amino acid content. Nutr Res 2008, 28:651-658.

11. Tang JE, Moore DR, Kujbida GW, Tarnopolsky MA, Phillips SM: Ingestion of whey hydrolysate, casein, or soy protein isolate: effects on mixed muscle protein synthesis at rest and following resistance exercise in young men. J Appl Physiol 2009, 107:987-992.

12. Andersen LL, Tufekovic G, Zebis MK, Crameri RM, Verlaan G, Kjaer M, Suetta $C$, Magnusson P, Aagaard P: The effect of resistance training combined with timed ingestion of protein on muscle fiber size and muscle strength. Metabolism 2005, 54:151-156.

13. Bird SP, Tarpenning KM, Marino FE: Independent and combined effects of liquid carbohydrate/essential amino acid ingestion on hormonal and muscular adaptations following resistance training in untrained men. Eur J Appl Physiol 2006, 97:225-238.

14. Cribb PJ, Williams AD, Stathis CG, Carey MF, Hayes A: Effects of whey isolate, creatine, and resistance training on muscle hypertrophy. Med SciSports Exerc 2007, 39:298-307.

15. Hartman JW, Tang JE, Wilkinson SB, Tarnopolsky MA, Lawrence RL, Fullerton AV, Phillips SM: Consumption of fat-free fluid milk after resistance exercise promotes greater lean mass accretion than does consumption of soy or carbohydrate in young, novice, male weightlifters. Am J Clin Nutr 2007, 86:373-381.

16. Burke DG, Chilibeck PD, Davidson KS, Candow DG, Farthing J, SmithPalmer T: The effect of whey protein supplementation with and without creatine monohydrate combined with resistance training on lean tissue mass and muscle strength. Int J Sport Nutr Exerc Metab 2001, 11:349-364. 
17. Candow DG, Burke NC, Smith-Palmer T, Burke DG: Effect of whey and soy protein supplementation combined with resistance training in young adults. Int J Sport Nutr Exerc Metab 2006, 16:233-244.

18. Kerksick CM, Rasmussen CJ, Lancaster SL, Magu B, Smith P, Melton C, Greenwood M, Almada AL, Earnest CP, Kreider RB: The effects of protein and amino acid supplementation on performance and training adaptations during ten weeks of resistance training. J Strength Cond Res 2006, 20:643-653.

19. Willoughby DS, Stout JR, Wilborn CD: Effects of resistance training and protein plus amino acid supplementation on muscle anabolism, mass, and strength. Amino Acids 2007, 32:467-477.

20. Hulmi JJ, Kovanen V, Selänne H, Kraemer WJ, Häkkinen K, Mero AA: Acute and long-term effects of resistance exercise with or without protein ingestion on muscle hypertrophy and gene expression. Amino Acids 2009, 37:297-308.

21. Esmarck B, Andersen JL, Olsen S, Richter EA, Mizuno M, Kjaer M: Timing of postexercise protein intake is important for muscle hypertrophy with resistance training in elderly humans. J Physiol 2001, 535:301-311.

22. Cribb PJ, Hayes A: Effects of supplement timing and resistance exercise on skeletal muscle hypertrophy. Med Sci Sports Exerc 2006 38:1918-1925

23. Ha E, Zemel MB: Functional properties of whey, whey components, and essential amino acids: mechanisms underlying health benefits for active people (review). J Nutr Biochem 2003, 14:251-258,

24. Etzel MR: Manufacture and use of dairy protein fractions. J Nutr 2004, 134:996S-1002S.

25. Krissansen GW: Emerging health properties of whey proteins and their clinical implications. J Am Coll Nutr 2007, 26:713S-23S.

26. Cribb PJ, Williams AD, Carey MF, Hayes A: The effect of whey isolate and resistance training on strength, body composition, and plasma glutamine. Int J Sport Nutr Exerc Metab 2006, 16:494-509.

27. Bucci L, Unlu L: Proteins and amino acid supplements in exercise and sport. In Energy-Yielding Macronutrients and Energy Metabolism in Sports Nutrition Edited by: Driskell L, Wolinsky I. CRC Press: Boca Raton, FL; 2000:191-212.

28. Häkkinen K, Pakarinen A, Kraemer WJ, Häkkinen A, Valkeinen H, Alen M: Selective muscle hypertrophy, changes in EMG and force, and serum hormones during strength training in older women. J Appl Physiol 2001, 91:569-580

29. Kraemer WJ, Adams K, Cafarelli E, Dudley GA, Dooly C, Feigenbaum MS, Fleck SJ, Franklin B, Fry AC, Hoffman JR, Newton RU, Potteiger J, Stone MH, Ratamess NA, Triplett-McBride T, American College of Sports Medicine: American College of Sports Medicine position stand. Progression models in resistance training for healthy adults. Med Sci Sports Exerc 2002, 34:364-380

30. Kraemer WJ, Ratamess NA: Fundamentals of resistance training: progression and exercise prescription. Med Sci Sports Exerc 2004 36:674-688.

31. Hulmi JJ, Ahtiainen JP, Kaasalainen T, Pöllänen E, Häkkinen K, Alen M, Selänne H, Kovanen V, Mero AA: Postexercise myostatin and activin llb mRNA levels: effects of strength training. Med Sci Sports Exerc 2007, 39:289-297.

32. Josse AR, Tang JE, Tarnopolsky MA, Phillips SM: Body Composition and Strength Changes in Women with Milk and Resistance Exercise. Med SciSports Exerc 2010, 42:1122-1130.

33. Olsen S, Aagaard P, Kadi F, Tufekovic G, Verney J, Olesen JL, Suetta C, Kjaer $\mathrm{M}$ : Creatine supplementation augments the increase in satellite cell and myonuclei number in human skeletal muscle induced by strength training. J Physiol 2006, 573:525-534.

34. Godard MP, Williamson DL, Trappe SW: Oral amino-acid provision does not affect muscle strength or size gains in older men. Med Sci Sports Exerc 2002, 34:1126-1131.

35. Candow DG, Chilibeck PD, Facci M, Abeysekara S, Zello GA: Protein supplementation before and after resistance training in older men. Eur J Appl Physiol 2006, 97:548-556.

36. Verdijk LB, Jonkers RA, Gleeson BG, Beelen M, Meijer K, Savelberg HH, Wodzig WK, Dendale P, van Loon LJ: Protein supplementation before and after exercise does not further augment skeletal muscle hypertrophy after resistance training in elderly men. Am J Clin Nutr 2009, 89:608-616.

37. Hulmi JJ, Tannerstedt J, Selänne H, Kainulainen H, Kovanen V, Mero AA Resistance exercise with whey protein ingestion affects mTOR signaling pathway and myostatin in men. J App/ Physio/ 2009, 106:1720-1729

38. Kukuljan S, Nowson CA, Sanders K, Daly RM: Effects of resistance exercise and fortified milk on skeletal muscle mass, muscle size, and functional performance in middle-aged and older men: an 18-mo randomized controlled trial. J Appl Physiol 2009, 107:1864-1873.

39. Katsanos CS, Kobayashi H, Sheffield-Moore M, Aarsland A, Wolfe RR: A high proportion of leucine is required for optimal stimulation of the rate of muscle protein synthesis by essential amino acids in the elderly. Am J Physiol Endocrinol Metab 2006, 291:E381-7.

40. Cuthbertson D, Smith K, Babraj J, Leese G, Waddell T, Atherton P, Wackerhage H, Taylor PM, Rennie MJ: Anabolic signaling deficits underlie amino acid resistance of wasting, aging muscle. FASEB J 2005, 19:422-424

41. Koopman R, Walrand S, Beelen M, Gijsen AP, Kies AK, Boirie Y, Saris WH, van Loon $L$ : Dietary protein digestion and absorption rates and the subsequent postprandial muscle protein synthetic response do not differ between young and elderly men. J Nutr 2009, 139:1707-1713.

42. Hubal MJ, Gordish-Dressman H, Thompson PD, Price TB, Hoffman EP Angelopoulos TJ, Gordon PM, Moyna NM, Pescatello LS, Visich PS, Zoeller RF, Seip RL, Clarkson PM: Variability in muscle size and strength gain after unilateral resistance training. Med Sci Sports Exerc 2005, 37:964-972.

43. Moon JR, Eckerson JM, Tobkin SE, Smith AE, Lockwood CM, Walter AA Cramer JT, Beck TW, Stout JR: Estimating body fat in NCAA Division I female athletes: a five-compartment model validation of laboratory methods. Eur J Appl Physiol 2009, 105:119-130.

44. Nosaka K, Sacco P, Mawatari K: Effects of amino acid supplementation on muscle soreness and damage. Int J Sport Nutr Exerc Metab 2006 16:620-635

45. Shimomura $Y$, Yamamoto $Y$, Bajotto G, Sato J, Murakami T, Shimomura $N$, Kobayashi H, Mawatari K: Nutraceutical effects of branched-chain amino acids on skeletal muscle. J Nutr 2006, 136:529S-532S.

46. Buckley JD, Thomson RL, Coates AM, Howe PR, DeNichilo MO, Rowney MK: Supplementation with a whey protein hydrolysate enhances recovery of muscle force-generating capacity following eccentric exercise. J SciMed Sport 2010, 13:178-181.

47. Cockburn E, Hayes PR, French DN, Stevenson E, St Clair Gibson A: Acute milk-based protein- $\mathrm{CHO}$ supplementation attenuates exerciseinduced muscle damage. Appl Physiol Nutr Metab 2008, 33:775-783.

48. Etheridge T, Philp A, Watt PW: A single protein meal increases recovery of muscle function following an acute eccentric exercise bout. Appl Physiol Nutr Metab 2008, 33:483-488.

49. Hoffman JR, Ratamess NA, Tranchina CP, Rashti SL, Kang J, Faigenbaum AD: Effect of a proprietary protein supplement on recovery indices following resistance exercise in strength/power athletes. Amino Acids 2010, 38:771-778.

50. Bird SP, Tarpenning KM, Marino FE: Liquid carbohydrate/essential amino acid ingestion during a short-term bout of resistance exercise suppresses myofibrillar protein degradation. Metabolism 2006, 55:570-577.

51. Hulmi JJ, Volek JS, Selänne H, Mero AA: Protein ingestion prior to strength exercise affects blood hormones and metabolism. Med Sc Sports Exerc 2005, 37:1990-1997.

52. Power $\mathrm{O}$, Hallihan A, Jakeman P: Human insulinotropic response to oral ingestion of native and hydrolysed whey protein. Amino Acids 2009, 37:333-339

53. Morifuji M, Kanda A, Koga J, Kawanaka K, Higuchi M: Post-exercise carbohydrate plus whey protein hydrolysates supplementation increases skeletal muscle glycogen level in rats. Amino Acids 2010 38:1109-1115

54. Morifuji M, Koga J, Kawanaka K, Higuchi M: Branched-chain amino acidcontaining dipeptides, identified from whey protein hydrolysates, stimulate glucose uptake rate in L6 myotubes and isolated skeletal muscles. J Nutr Sci Vitaminol (Tokyo) 2009, 55:81-86.

55. Karlsson HK, Nilsson PA, Nilsson J, Chibalin AV, Zierath JR, Blomstrand E: Branched-chain amino acids increase p7056k phosphorylation in human skeletal muscle after resistance exercise. Am J Physiol Endocrinol Metab 2004, 287:E1-7.

56. Blomstrand E, Eliasson J, Karlsson HK, Kohnke R: Branched-chain amino acids activate key enzymes in protein synthesis after physical exercise. J Nutr 2006, 136:269S-73S. 
57. Koopman R, Pennings $B$, Zorenc $A H$, van Loon LJ: Protein ingestion further augments $\mathrm{S} 6 \mathrm{~K} 1$ phosphorylation in skeletal muscle following resistance type exercise in males. J Nutr 2007, 137:1880-1886.

58. Buse MG, Reid SS: Leucine. A possible regulator of protein turnover in muscle. J Clin Invest 1975, 56:1250-1261.

59. Anthony JC, Yoshizawa F, Anthony TG, Vary TC, Jefferson LS, Kimball SR: Leucine stimulates translation initiation in skeletal muscle of postabsorptive rats via a rapamycin-sensitive pathway. J Nutr 2000, 130:2413-2419.

60. Kimball SR, Jefferson LS: New functions for amino acids: effects on gene transcription and translation. Am J Clin Nutr 2006, 83:500S-507S.

61. Atherton PJ, Smith K, Etheridge T, Rankin D, Rennie MJ: Distinct anabolic signalling responses to amino acids in C2C12 skeletal muscle cells. Amino Acids 2010, 38:1533-1539.

62. Gulati P, Gaspers LD, Dann SG, Joaquin M, Nobukuni T, Natt F, Kozma SC, Thomas AP, Thomas G: Amino acids activate mTOR complex 1 via Ca2+/ CaM signaling to hVps34. Cell Metab 2008, 7:456-465.

63. Sancak Y, Peterson TR, Shaul YD, Lindquist RA, Thoreen CC, Bar-Peled L, Sabatini DM: The Rag GTPases bind raptor and mediate amino acid signaling to mTORC1. Science 2008, 320:1496-1501.

64. Kim E, Goraksha-Hicks P, Li L, Neufeld TP, Guan KL: Regulation of TORC1 by Rag GTPases in nutrient response. Nat Cell Biol 2008, 10:935-945.

65. Avruch J, Long X, Ortiz-Vega S, Rapley J, Papageorgiou A, Dai N: Amino acid regulation of TOR complex 1. Am J Physiol Endocrinol Metab 2009 296:E592-602.

66. Findlay GM, Yan L, Procter J, Mieulet V, Lamb RF: A MAP4 kinase related to Ste20 is a nutrient-sensitive regulator of mTOR signalling. Biochem J 2007, 403:13-20.

67. Thalacker-Mercer AE, Fleet JC, Craig BA, Carnell NS, Campbell WW: Inadequate protein intake affects skeletal muscle transcript profiles in older humans. Am J Clin Nutr 2007, 85:1344-1352.

68. Malumbres M, Ortega S, Barbacid M: Genetic analysis of mammalian cyclin-dependent kinases and their inhibitors. Biol Chem 2000, 381:827-838.

69. Berthet C, Aleem E, Coppola V, Tessarollo L, Kaldis P: Cdk2 knockout mice are viable. Curr Biol 2003, 13:1775-1785

70. Hulmi JJ, Kovanen V, Lisko I, Selänne H, Mero AA: The effects of whey protein on myostatin and cell cycle-related gene expression responses to a single heavy resistance exercise bout in trained older men. Eur J Appl Physiol 2008, 102:205-213.

71. Ratamess NA, Kraemer WJ, Volek JS, Rubin MR, Gomez AL, French DN, Sharman MJ, McGuigan MM, Scheett T, Häkkinen K, Newton RU, Dioguardi F: The effects of amino acid supplementation on muscular performance during resistance training overreaching. J Strength Cond Res 2003, 17:250-258.

72. Kerksick C, Harvey T, Stout J, Campbell B, Wilborn C, Kreider R, Kalman D, Ziegenfuss T, Lopez H, Landis J, Ivy JL, Antonio J: International Society of Sports Nutrition position stand: Nutrient timing. J Int Soc Sports Nutr 2008, 5:17.

73. Tipton KD, Rasmussen BB, Miller SL, Wolf SE, Owens-Stovall SK, Petrini BE, Wolfe RR: Timing of amino acid-carbohydrate ingestion alters anabolic response of muscle to resistance exercise. Am J Physiol Endocrinol Metab 2001, 281:E197-206.

74. Levenhagen DK, Gresham JD, Carlson MG, Maron DJ, Borel MJ, Flakoll PJ: Postexercise nutrient intake timing in humans is critical to recovery of leg glucose and protein homeostasis. Am J Physiol Endocrinol Metab 2001, 280:E982-93.

75. Biolo G, Tipton KD, Klein S, Wolfe RR: An abundant supply of amino acids enhances the metabolic effect of exercise on muscle protein. Am J Physiol 1997, 273:E122-9.

76. Phillips SM, Tipton KD, Aarsland A, Wolf SE, Wolfe RR: Mixed muscle protein synthesis and breakdown after resistance exercise in humans. Am J Physiol 1997, 273:E99-107.

77. Burd NA, Tang JE, Moore DR, Phillips SM: Exercise training and protein metabolism: influences of contraction, protein intake, and sex-based differences. J Appl Physio/ 2009, 106:1692-1701.

78. Hoffman JR, Ratamess NA, Tranchina CP, Rashti SL, Kang J, Faigenbaum AD: Effect of protein-supplement timing on strength, power, and bodycomposition changes in resistance-trained men. Int J Sport Nutr Exerc Metab 2009, 19:172-185.
79. Boirie Y, Dangin M, Gachon P, Vasson MP, Maubois JL, Beaufrere B: Slow and fast dietary proteins differently modulate postprandial protein accretion. Proc Nat Acad Sci USA 1997, 94:14930-14935.

80. Burk A, Timpmann S, Medijainen L, Vahi M, Oopik V: Time-divided ingestion pattern of casein-based protein supplement stimulates an increase in fat-free body mass during resistance training in young untrained men. Nutr Res 2009, 29:405-413.

81. Tang JE, Perco JG, Moore DR, Wilkinson SB, Phillips SM: Resistance training alters the response of fed state mixed muscle protein synthesis in young men. Am J Physiol Regul Integr Comp Physiol 2008, 294:R172-8

82. Beelen M, Tieland M, Gijsen AP, Vandereyt $H$, Kies AK, Kuipers $H$, Saris WH, Koopman R, van Loon LJ: Coingestion of carbohydrate and protein hydrolysate stimulates muscle protein synthesis during exercise in young men, with no further increase during subsequent overnight recovery. J Nutr 2008, 138:2198-2204.

83. Beelen M, Koopman R, Gijsen AP, Vandereyt H, Kies AK, Kuipers H, Saris $\mathrm{WH}$, van Loon $\mathrm{L}$ : Protein coingestion stimulates muscle protein synthesis during resistance-type exercise. Am J Physiol Endocrinol Metab 2008, 295:E70-7.

84. Fujita S, Dreyer HC, Drummond MJ, Glynn EL, Volpi E, Rasmussen BB: Essential amino acid and carbohydrate ingestion before resistance exercise does not enhance postexercise muscle protein synthesis. $J$ Appl Physiol 2009, 106:1730-1739.

85. Rasmussen BB, Phillips SM: Contractile and nutritional regulation of human muscle growth. Exerc Sport Sci Rev 2003, 31:127-131.

86. Moore DR, Robinson MJ, Fry JL, Tang JE, Glover El, Wilkinson SB, Prior T, Tarnopolsky MA, Phillips SM: Ingested protein dose response of muscle and albumin protein synthesis after resistance exercise in young men. Am J Clin Nutr 2009, 89:161-168.

87. Symons TB, Sheffield-Moore M, Wolfe RR, Paddon-Jones D: A moderate serving of high-quality protein maximally stimulates skeletal muscle protein synthesis in young and elderly subjects. J Am Diet Assoc 2009, 109:1582-1586.

88. Arnal MA, Mosoni L, Boirie $Y$, Houlier ML, Morin L, Verdier E, Ritz P, Antoine JM, Prugnaud J, Beaufrere B, Mirand PP: Protein pulse feeding improves protein retention in elderly women. Am J Clin Nutr 1999, 69:1202-1208.

89. Raastad T, Fostervold T, Hansen O, Hansen EA, Garthe I, Refsnes E: The effect of meal frequency on accumulation of muscle mass and strength during 12 weeks of strength training.[abstract]. Book of abstracts, ICST 5th Congress, Odense 2006.

90. Tipton KD, Elliott TA, Cree MG, Wolf SE, Sanford AP, Wolfe RR: Ingestion of casein and whey proteins result in muscle anabolism after resistance exercise. Med Sci Sports Exerc 2004, 36:2073-2081.

91. Brown EC, DiSilvestro RA, Babaknia A, Devor ST: Soy versus whey protein bars: effects on exercise training impact on lean body mass and antioxidant status. Nutr J 2004, 3:22

92. Kalman D, Feldman S, Martinez M, Krieger DR, Tallon MJ: Effect of protein source and resistance training on body composition and sex hormones. J Int Soc Sports Nutr 2007, 4:4

93. Phillips SM, Tang JE, Moore DR: The role of milk- and soy-based protein in support of muscle protein synthesis and muscle protein accretion in young and elderly persons. J Am Coll Nutr 2009, 28:343-354.

94. Fouillet H, Mariotti F, Gaudichon C, Bos C, Tome D: Peripheral and splanchnic metabolism of dietary nitrogen are differently affected by the protein source in humans as assessed by compartmental modeling. J Nutr 2002, 132:125-133.

95. Koopman R, Crombach N, Gijsen AP, Walrand S, Fauquant J, Kies AK Lemosquet S, Saris WH, Boirie Y, van Loon LJ: Ingestion of a protein hydrolysate is accompanied by an accelerated in vivo digestion and absorption rate when compared with its intact protein. Am J Clin Nutr 2009, 90:106-115.

96. Dangin M, Boirie Y, Garcia-Rodenas C, Gachon P, Fauquant J, Callier P, Ballevre $O$, Beaufrere $B$ : The digestion rate of protein is an independent regulating factor of postprandial protein retention. Am J Physiol Endocrinol Metab 2001, 280:E340-8.

97. Dangin M, Guillet C, Garcia-Rodenas C, Gachon P, Bouteloup-Demange C, Reiffers-Magnani K, Fauquant J, Ballevre O, Beaufrere B: The rate of protein digestion affects protein gain differently during aging in humans. J Physio/ 2003, 549:635-644. 
98. Campbell WW, Barton ML Jr, Cyr-Campbell D, Davey SL, Beard JL, Parise G, Evans WJ: Effects of an omnivorous diet compared with a lactoovovegetarian diet on resistance-training-induced changes in body composition and skeletal muscle in older men. Am J Clin Nutr 1999, 70:1032-1039.

99. Haub MD, Wells AM, Tarnopolsky MA, Campbell WW: Effect of protein source on resistive-training-induced changes in body composition and muscle size in older men. Am J Clin Nutr 2002, 76:511-517.

100. Symons TB, Schutzler SE, Cocke TL, Chinkes DL, Wolfe RR, Paddon-Jones D: Aging does not impair the anabolic response to a protein-rich meal. Am J Clin Nutr 2007, 86:451-456.

101. Kunz C, Lonnerdal B: Re-evaluation of the whey protein/casein ratio of human milk. Acta Paediatr 1992, 81:107-112.

102. Zhang H, Yao J, Zhao D, Liu H, Li J, Guo M: Changes in chemical composition of Alxa bactrian camel milk during lactation. J Dairy Sci 2005, 88:3402-3410

103. D'Amato A, Bachi A, Fasoli E, Boschetti E, Peltre G, Senechal H, Righetti PG: In-depth exploration of cow's whey proteome via combinatorial peptide ligand libraries. J Proteome Res 2009, 8:3925-3936.

104. Yalcin AS: Emerging therapeutic potential of whey proteins and peptides. Curr Pharm Des 2006, 12:1637-1643.

105. Rieu I, Balage M, Sornet C, Debras E, Ripes S, Rochon-Bonhomme C, Pouyet C, Grizard J, Dardevet D: Increased availability of leucine with leucine-rich whey proteins improves postprandial muscle protein synthesis in aging rats. Nutrition 2007, 23:323-331.

106. Norton LE, Layman DK, Bunpo P, Anthony TG, Brana DV, Garlick PJ: The leucine content of a complete meal directs peak activation but not duration of skeletal muscle protein synthesis and mammalian target of rapamycin signaling in rats. J Nutr 2009, 139:1103-1109.

107. Nolles JA, Verreijen AM, Koopmanschap RE, Verstegen MW, Schreurs VV: Postprandial oxidative losses of free and protein-bound amino acids in the diet: interactions and adaptation. J Anim Physiol Anim Nutr (Berl) 2008 in press.

108. Borsheim E, Tipton KD, Wolf SE, Wolfe RR: Essential amino acids and muscle protein recovery from resistance exercise. Am J Physiol Endocrinol Metab 2002, 283:E648-57.

109. Smith K, Reynolds N, Downie S, Patel A, Rennie MJ: Effects of flooding amino acids on incorporation of labeled amino acids into human muscle protein. Am J Physiol 1998, 275:E73-8.

110. Dangin M, Boirie Y, Guillet C, Beaufrere B: Influence of the protein digestion rate on protein turnover in young and elderly subjects. Nutr 2002, 132:3228S-33S.

111. Pilvi TK, Harala S, Korpela R, Mervaala EM: Effects of high-calcium diets with different whey proteins on weight loss and weight regain in highfat-fed C57BL/6J mice. Br J Nutr 2009, 102:337-341

112. Fouillet H, Gaudichon C, Mariotti F, Bos C, Huneau JF, Tome D: Energy nutrients modulate the splanchnic sequestration of dietary nitrogen in humans: a compartmental analysis. Am J Physiol Endocrinol Metab 2001, 281:E248-60.

113. Calbet JA, Holst JJ: Gastric emptying, gastric secretion and enterogastrone response after administration of milk proteins or their peptide hydrolysates in humans. Eur J Nutr 2004, 43:127-139.

114. Elliot TA, Cree MG, Sanford AP, Wolfe RR, Tipton KD: Milk ingestion stimulates net muscle protein synthesis following resistance exercise. Med Sci Sports Exerc 2006, 38:667-674.

115. Carunchia Whetstine ME, Croissant AE, Drake MA: Characterization of dried whey protein concentrate and isolate flavor. J Dairy Sci 2005 , 88:3826-3839.

116. Manninen AH: Protein hydrolysates in sports nutrition. Nutr Metab (Lond) 2009, 6:38.

117. Tello PG, Camacho F, Jurado E, Paez MP, Guadix EM: Enzymatic hydrolysis of whey proteins. II. Molecular-weight range. Biotechnol Bioeng 1994, 44:529-532.

118. Paddon-Jones D, Sheffield-Moore M, Katsanos CS, Zhang XJ, Wolfe RR: Differential stimulation of muscle protein synthesis in elderly humans following isocaloric ingestion of amino acids or whey protein. Exp Gerontol 2006, 41:215-219.

119. Terada T, Inui K: Peptide transporters: structure, function, regulation and application for drug delivery. Curr Drug Metab 2004, 5:85-94.

120. Kimball SR: The role of nutrition in stimulating muscle protein accretion at the molecular level. Biochem Soc Trans 2007, 35:1298-1301.
121. Nair KS, Schwartz RG, Welle S: Leucine as a regulator of whole body and skeletal muscle protein metabolism in humans. Am J Physiol 1992, 263:E928-34.

122. Koopman R, Verdijk LB, Beelen M, Gorselink M, Kruseman AN, Wagenmakers AJ, Kuipers $H$, van Loon LJ: Co-ingestion of leucine with protein does not further augment post-exercise muscle protein synthesis rates in elderly men. Br J Nutr 2007:1-10.

123. Tipton KD, Elliott TA, Ferrando AA, Aarsland AA, Wolfe RR: Stimulation of muscle anabolism by resistance exercise and ingestion of leucine plus protein. Appl Physiol Nutr Metab 2009, 34:151-161.

124. Verhoeven S, Vanschoonbeek K, Verdijk LB, Koopman R, Wodzig WK, Dendale $P$, van Loon $\sqcup$ : Long-term leucine supplementation does not increase muscle mass or strength in healthy elderly men. Am J Clin Nutr 2009, 89:1468-1475.

doi: $10.1186 / 1743-7075-7-51$

Cite this article as: Hulmi et al., Effect of protein/essential amino acids and resistance training on skeletal muscle hypertrophy: A case for whey protein Nutrition \& Metabolism 2010, 7:5

\section{Submit your next manuscript to BioMed Central and take full advantage of:}

- Convenient online submission

- Thorough peer review

- No space constraints or color figure charges

- Immediate publication on acceptance

- Inclusion in PubMed, CAS, Scopus and Google Scholar

- Research which is freely available for redistribution
C Biomed Central 